\title{
SALIVARY PROFILE AND IDENTIFICATION OF EXISTING CANDIDA sp OF AN INSTITUTIONALIZED ELDERLY POPULATION IN JAKARTA
}

\author{
(PROFIL SALIVA DAN IDENTIFIKASI KEBERADAAN CANDIDA sp \\ PADA LANSIA DI PANTI JOMPO DI JAKARTA )
}

\author{
Febrina Rahmayanti, Yuniardini Septorini Wimardhani, Indriasti Wardhany \\ Department of Oral Medicine \\ Faculty of Dentistry, Universitas Indonesia \\ Jl. Salemba 4 Jakarta Pusat \\ E-mail: febrina_r@ui.ac.id/febrina_rahmayanti@yahoo.com
}

\begin{abstract}
Saliva plays an important role to protect oral and dental health, in maintenance oral microflora balance. In elderly, disease, and medications usually influence the saliva. The purpose of this preliminary study was to investigate salivary profile, oral symptoms of dryness, and existing of Candida sp of an institutionalized elderly in Jakarta, Twenty seven (27) elderly (17 men and 10 women) were examined in a cross sectional study. Unstimulated whole saliva was collected for 5 minutes, according to published protocol, and then salivary flow rate and $\mathrm{pH}$ were measured. Candida sp were cultured in CHROM agar. The yeasts were counted and identified. Oral symptom or complaints of oral dryness, and burning or itching were recorded with an interview. Data of systemic conditions and medication the used were obtained from the medical record. Eighteen (66.7\%) CHROM agar plates were Candida sp positive cultured, and about $61.1 \%$ subjects' salivary $\mathrm{pH}$ were below normal range. Twenty one (77.8\%) subjects had oral symptom and complain about oral dryness, even thought the salivary flow rate were in normal range. In this study, C.albicans is not the most frequently found colonized. About $72 \%$ were identified not C.albicans. This study suggests that, in elderly which salivary pH was below normal range have greater opportunistic infected by Candida sp. It can be concluded that, the result did not confirm a significant difference between subjects' data and salivary profile concentration. The mycological finding Candida albicans is not the most frequently found colonized in this elderly population. Further study which lagger elderly population and might give deeper insights of salivary profile in this population.
\end{abstract}

Key words: salivary flow rate, salivary $\mathrm{pH}$, Candida $\mathrm{sp}$

\begin{abstract}
Abstrak
Saliva memiliki peranan penting dalam melindungi kesehatan rongga mulut dan gigi, dalam hal menjaga keseimbangan mikro flora oral. Pada orang lanjut usia, penyakit dan pengobatan biasanya mempengaruhi saliva. Tujuan studi ini adalah untuk menginvestigasi profil saliva, gejala kekeringan oral, dan adaanya Candida $s p$ di suatu institusi lansia di Jakarta, Indonesia. Dus puluh tujuh (27) orang lansia (17 pria dan 17 wanita) di periksa pada studi cross sectional. Saliva tanpa stimulasi dikumpulkan selama 5 menit, sesuai dengan protokol, dan kemudian rerata laju saliva dan pH saliva diukur. Candida sp dikultur di CHROM agar. Yeasts yang ada dihitung dan diidentifikasi. Gejala oral ataupun keluhan terhadap mulut kering dan rasa terbakar atau gatal direkam dalam suatu wawancara. Data kondisi sistemik dan riwayat kesehatan diperoleh dari rekam medis. Delapan belas $(66,7 \%)$ agar CHROM positif candida sp dan sekitar $61,1 \%$ pH saliva subjek dibawah batas normal. Dua puluh satu $(77,8 \%)$ subjek memiliki gejala dan keluhan mulut kering walaupun rerata laju salivanya dalam batas normal. Pada studi ini, C.albicans bukanlah koloni bakteri yang paling anyak dijumpai. Sekitar $72 \%$ bakteri yang teridentifikasi bukan C.albicans. Pada studi ini menemukan pada lansia dengan $\mathrm{pH}$ saliva dibawah normal memiliki kemungkinan yang lebih tinggi terinfeksi oleh Candida sp. Penelitian lebih lanjut dengan populasi yang lebih besar dan mungkin dapat memberikan gambaran prifil saliva yang lebih dalam pada populasi ini.
\end{abstract}

Kata kunci: rerata laju saliva, $\mathrm{pH}$ saliva, Candida $s p$

\section{INTRODUCTION}

Among countries worldwide, developing countries are facing the fastest growth of elderly population. ${ }^{1}$ Health maintenance of this population is a very important issue for these countries, since changing in 
disease pattern would be expected. Indonesia as a country in the fifth largest population would need to pay more attention on the burden of chronic diseases and related impacts in elderly quality of life. Oral health status of elderly would also have impacts in general health and quality of life.

Saliva is a key in oral homeostasis. It is important to maintain oral and dental health, due to its organic and anorganic component. Saliva plays an important role in maintenance oral microflora balance. In old age, disease, and using medication usually influence saliva. Therefore, its alteration in terms of quantity, quality and composition would interfere oral homeostasis. ${ }^{2}$ Several studies have included in salivary flow rate, $\mathrm{pH}$ and buffering capacity to assess salivary function and determine salivary profile. ${ }^{3,4}$ The changing in salivary profile in elderly may influence capability in maintaining oral microflora balance. This condition may give different profile of microflora of oral cavity, which is responsible to the type of infection happened in this population. Candida $s p$ is a normal microflora in oral cavity. There is individual level of Candida carriage that is correlated with age and general health condition. Risk of candida infection is increased in paralel with age. Candida $s p$ is the common causative agent of fungal infection in oral cavity with Candida albicans is the most common species involved. Opportunistic infection caused by Candida $s p$ is one of the infection that may be caused by the changing of salivary profile in elderly. Other risk factor of this infection includes high usage of dentures in the elderly population that may become a reservoir for Candida $s p$. However, it is not known whether Candida albicans is still the causative agent of the presence of fungal infection in elderly. ${ }^{5}$

To date, data on the condition of salivary profile and its relation to the status of Candida $s p$ in elderly population in Indonesia is still not well documented. The objective of this research was to investigate salivary profile (protein concentration, salivary flow rate, and $\mathrm{pH}$ ), oral symptoms of dryness, and existing of Candida $s p$ in an institutionalized elderly population in Jakarta, Indonesia. This study would provide additional information regarding to elderly in Indonesia.

\section{MATERIALS AND METHODS}

Twenty-seven elderly (17 men and 10 women) were examined in a cross sectional study. Approval to undertake this study was obtained from the Institutional Ethics Committee of Faculty of Dentistry Universitas Indonesia, and informed consent was obtained from all subjects. We also interviewed their complaints of oral dryness and burning sensation or itching. Single unstimulated whole saliva sample was collected from each subject for 5 minutes, according to published protocol, and then salivary flow rate and $\mathrm{pH}$ were measured.

All of saliva samples were kept on ice during collecting. The collected specimens were soon centrifuged at $4600 \mathrm{rpm}$ for 5 minutes in $4^{\circ} \mathrm{C}$ to remove microorganisms, and desquamated epithelial cells. The supernatants and pellets were kept in $-20^{\circ} \mathrm{C}$ until used for analysis. The supernatants were used to analyze total saliva concentration from each sample, and were calculated using Bradford method. Then the pellet was diluted using $5 \mathrm{ml}$ PBS, and Candida $s p$ were cultured in specific culture media, CHROM agar by taking $50 \mu$ l diluted pellet, incubated in $37^{\circ} \mathrm{C}$, for 48 hours. The characterization of Candida $s p$ was carried out by isolation in CHRO Magar, a sensitive and specific method for presumptive identification of yeast species, most commonly used for Candida $s p$. The yeasts were counted and identified. The presence of oral symptom or complain of oral dryness, and burning or itching was recorded with an interview. Data of systemic condition and medication their used were obtained from the medical record.

\section{RESULT}

The study involved 27 elderly, of whom 17 men and 10 women. The characteristic of the subjectswas described in Table 1. This demographic data obtained from anamnesis and confirmed the patient's medical record books, which was then recorded in research examination sheet. Based on gender, $63 \%$ of the subjects were male, and all subjects were over 60 years old, with the highest age range 60-65 years $(55.5 \%)$.

We identified subjects with oral dryness's complain by interview. Twenty-one (77.8\%) subjects had oral complaints about oral dryness (non xerostomia), and $6(22.2 \%)$ subjects had no oral complaints of dryness (xerostomia). The mean of unstimulated salivary flow rate was $1.78 \pm 0.424 \mathrm{ml} / \mathrm{m}$ and $6(22.2 \%)$ elderly classified hyposalivation, while $21(77.8 \%)$ subjects had normal salivary flow rate (Figure 1).

Twenty-two (81.5\%) subjects had salivary acidic $\mathrm{pH}$, and only about 5 (18.5\%) who were at normal $\mathrm{pH}$ range (Figure 2). In elderly, which salivary $\mathrm{pH}$ were below normal range had greater opportunistic infected by Candida $s p$.

Salivary profile of study subjects were in the range of very varied, with the mean concentration of total salivary protein in this population was $1369 \mu \mathrm{g} / \mathrm{ml}$ 
(SD \pm 669.6) (Figure 3). Salivary profiles of study subjects were not significantly related to the presence of Candida sp. Furthermore, subjects' data on age, sex, salivary flow rate and salivary $\mathrm{pH}$ did not significantly influence the total salivary protein concentration.

Table 1. Characteristic of elderly based on gender, age, education, systemic diseases, smoking habit, salivary flow rate, and saliva $\mathrm{pH}$.

\begin{tabular}{lcc}
\hline Characteristic of subjects & $\mathrm{n}$ & $\%$ \\
\hline Gender & 17 & 63 \\
Male & 10 & 37 \\
Female & & \\
Age (year) & 15 & 55.5 \\
$60-65$ & 3 & 11.1 \\
$66-71$ & 4 & 14.8 \\
$72-76$ & 3 & 11.1 \\
$77-81$ & 1 & 3.7 \\
$82-86$ & 1 & 3.7 \\
$87-91$ & & \\
Education & 4 & 14.8 \\
No formal education & 10 & 37 \\
Primary & 7 & 25.9 \\
Junior high & 4 & 14.8 \\
Senior high & 2 & 7.4 \\
Academy & 0 & 0 \\
University & & \\
Systemic diseases & 20 & 74 \\
Yes & 7 & 26 \\
No & & 66.7 \\
Smoking & 18 & 33.3 \\
Yes & 9 & \\
No & & \\
\hline
\end{tabular}

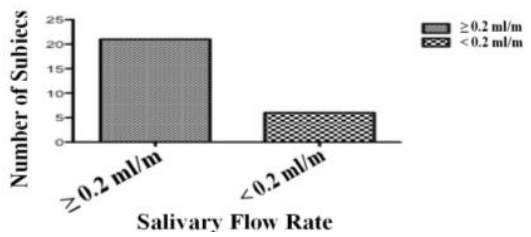

Figure 1. Distribution of subjects’ salivary flow rate

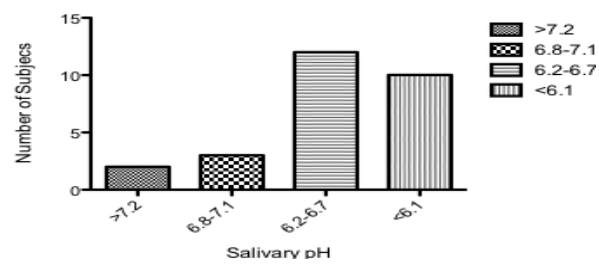

Figure 2. Distribution of subjects' salivary $\mathrm{pH}$

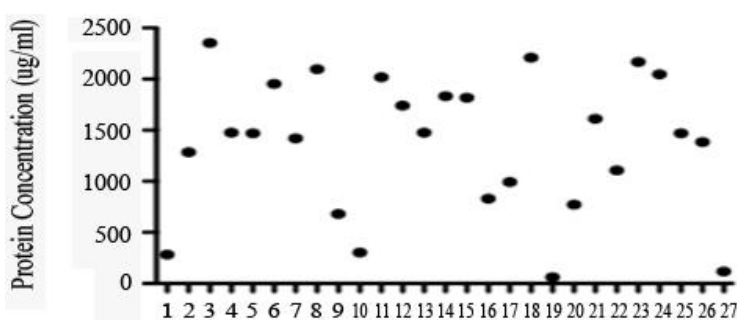

Figure 3. Distribution of total salivary protein concentration
A total of 27 isolates were screened for their abilities to grow and for their colony colors in CHROM agar (Figure 4).

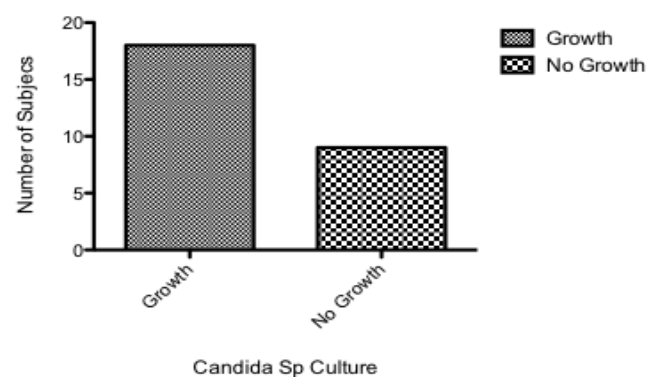

Figure 4. Presence of Candida sp culture

Eighteen (66.7\%) CHROM agar plates was Candida $s p$ positive culture. In this study, Candida albicans the most frequently found colonized. It was observed only 7 (38.9\%) of culture Candida albicans' positive, which is determined based on colony color. About 11 (61.1\%) were identified not Candida albicans. Candida tropicalis had been found in $6(54.5 \%)$ subjects, and the remaint, $5(45.5 \%)$ subjects were identified as the growth of Candida krusei's yeast.

\section{DISCUSSION}

The analysis of our data showed that eighteen $(66.7 \%)$ subjects with a positive culture of Candida $s p$, and about $61.1 \%$ subjects of salivary $\mathrm{pH}$ were below normal range. But there was us tendency of influence of salivary flow rate. The prevalence of xerostomia increases with age, and it is approximately $30 \%$ of 65 years and older. ${ }^{2}$ There are some controversies about salivary flow rate changes in elderly. Some previous research showed that there were tendencies of changes, but some research showed that the relationship about aging and salivary flow rate change. ${ }^{6}$ In this present study, only 6 $(22.2 \%)$ subjects with hyposalivation. This condition may have happen, because the age of whole subjects of this research dominantly in early elderly, 60-65 years old. A Continuous salivary flow is an important thing to protect oral environment from infection. In healthy elderly the unstimulated whole saliva rate exceeds $0.2 \mathrm{ml} /$ minutes. Based on the result of sialometry, about $21(77.8 \%)$ subject had normal salivary flow rate. Twenty-one $(77.8 \%)$ subjects was had oral symptom and complaint about oral dryness, eventhough salivary flow rate was in normal range.This may be due to a lot of subjects aged less than 65 years, so that the salivary glands still functioning properly. Complaint of dry mouth may be simply due to the lack of drinking water. 
In elderly, systemic diseases, such as Diabetes mellitus and also malnutrition can also be a predisposing factor to candidiasis. ${ }^{7}$ Beside, the medicine used to treat systemic diseases could change the local factors in saliva. It has been determined that the principal control of salivary secretion is mediated by innervations. The medicine used could influence salivary glands either through nerve system or directly to the glands. In this study there were no correlations between systemic disease and salivary glands. This may be caused by drugs used instead of xerogenic agents. Besides, there is no detail data about systemic health status. Subjects usually come to the local clinic in their institution for some medication to relief their subjective health complain. The health cares and general doctor have done the general and screening examination about their health problems. In our investigation, we only found symptomatic therapy and multivitamins given by there without specific examination, written down in their medical status. According to this situation, the definitive diagnosis of systemic diseases could not be declared, only by the review of system of each subject. Subjects with hyposalivation had no specific systemic disorder, but it is interesting, about $66.7 \%$ of the subject were smokers. Smoking can cause dry mouth, but in this present study, only six subjects had hyposalivation. Smoking can lead oral epithelial alteration to help colonization of Candida $s p$, and all of smokers in this study had positive Candida culture. $^{8}$

The risk of Candida infection is increased in elderly. Kleinegger et al reported that Candida albicans was a predominant species in elderly population. ${ }^{9}$ Lund GR also reported that Candida albicans is the most isolated species from oral cavity of patients more than 60 years old. ${ }^{10}$ But in this present study we observed non-albicans Candida dominantly found in this population, and Candida alibicans only found in less than $40 \%$ subjects. A crescent frequently of non-albican Candida species has been reported in the last decade. In this study $55.6 \%$ had C.tropicalis. It had been documented that tropical Candida was found as the second most common isolated from betel quit chewers in Cambodian. Appoximately $66 \%$ of our subjects were cigarettesmokers. Oral environment of cigarette-smokers may give contribution to the development Candida $s p$. Hence until now there is no significant data about this relation. ${ }^{11}$ About $44.4 \%$ subjects with positive Candida's culture showed the growth of Candida krusei. Samaranayake stated that Candida krusei had been found in HIV/AIDS patients dominantly Thailand. Reichart et al found oral carriage of Candida krusei in there surveillance study were in Leprosy patients in Northern Thailand. ${ }^{12} \mathrm{We}$ could not predict the relation between the growth of Candida krusei and subjects systemic condition in this present study, because there was no diagnosis clarification of systemic diseases in medical records, and only the subjective complaints without specific objective examination. It can to concluded that, the result did not confirm a significant difference between subjects' data and salivary profile concentration. The mycological finding Candida albicans is not the most frequently found colonized in this elderly population. Further study which includes bigger elderly population required to confirm this result, and might give deeper insights of salivary profile in this population.

\section{ACKNOWLEDGMENT}

The authors are very grateful to all participants in this study. It was funded by a Grant Scheme of Riset Unggulan Universitas Indonesia 2011.

\section{References}

1. Petersen PE, Yamamoto T. Improving the oral health of older people: the approach of the WHO Global Oral Health Programme. Community Dent Oral Epidemiol 2005; 33: 81-92.

2. Gupta A, Epstein JB, Sroussi H. Hyposalivation in elderly patients. J Can Dent Assoc 2006; 72: 841-6.

3. Satoh-Kuriwada S, Shoji N, Kawai M, Uneyama K, Kaneta N, Sasano T. Hyposalivation strongly influences hypogeusia in the elderly. J Health Sci 2009; 55: 689-98.

4. Von Bültzingslöwen I, Sollecito TP, Fox PC, Daniels T. Salivary dysfunction associated with systemic diseases: systematic review and clinical management recommendations. Oral Surg Oral Med Oral Pathol Oral Radiol Endod 2007; 103 (suppl 1); S57.e1.S57.e15.

5. Gasparoto TH, Sipert CR, de Oliveira CE, Porto VC, Santos CF, Campanelli AP, Lara VS. Salivary immunity in elderly individuals presented with Candida-related denture stomatitis. Gerodontology 2012 Jun; 29(2): e331-9.

6. Bergdahl M. Salivary flow and oral complaint in adult dental patients. Community Dent Oral Epidemiol 2000; 28: 59-66.

7. Sganga G. Fungal infections in immunocompromised patients. Mycoses.2011.54(4): 1-3.

8. Wyk CV, Steenkamp V. Host factors affecting oral candidiasis. South Afr J Epidemiol Infect 2011; 26(1): 18-21.

9. Kleinegger CL, Lochkart SR, Vargas K, Soll DR. Frequency, intensity, species and strain of oral Candida vary as a function of host age. J ClinMicrobiol. 1996. 34(9): 2246-54. 
10. Lund RG, da Silva Nascente P, Etges A, Ribeiro GA, Rosalen PL, Del Pino FA. Occurrence, isolation and differentiation of Candida spp. and prevalence of variables associated to chronic atrophic candidiasis. Mycoses 2010; 53(3): 232-8.

11. Samaranayake L. Commensal oral Candida in Asia cohorts. Int J Oral Sci 2009.1(1): 2-5.

12. Reichart PA, Samaranayake LP, BendickCh, Schmidt-Westhausen AM, Jayatilake JA. Prevalence of oral Candida species in leprosy patients from Cambodia and Thailand. J Oral Pathol Med 2007; 36(6): 342-6. 